\title{
New paradigms in whole genome sequencing: from lab bench to cell phone
}

\author{
Jonathan O'Halloran
}

From International Conference on Human Genetics and 39th Annual Meeting of the Indian Society of Human Genetics (ISHG)

Ahmadabad, India. 23-25 January 2013

The DNA sequencing \& MDx fields have seen dramatic advances since the first draft of the human genome was published, with companies reporting ever faster and cheaper methods. However, despite the race to attain the $\$ 1000$ genome producing a plethora of exciting technologies, capillary electrophoresis (CE) is still being routinely used for targeted clinical sequencing and expensive real time PCR devices are still the work-horse of the MDx laboratory. QuantuMDx is developing a portable, handheld DNA sequencing device for PGx and infectious disease applications, to provide an alternative to slow and relatively expensive CE DNA sequencing \& expensive slow and lab based MDx \& CDx.

Published: 21 January 2014

doi:10.1186/1755-8166-7-S1-127

Cite this article as: $\mathrm{O}^{\prime} \mathrm{Halloran}$ : New paradigms in whole genome

sequencing: from lab bench to cell phone. Molecular Cytogenetics 2014

7(Suppl 1):127.

Submit your next manuscript to BioMed Central and take full advantage of:

- Convenient online submission

- Thorough peer review

- No space constraints or color figure charges

- Immediate publication on acceptance

- Inclusion in PubMed, CAS, Scopus and Google Scholar

- Research which is freely available for redistribution 